\title{
Molecular and morphological evidence of Alvinellidae relationships (Terebelliformia, Polychaeta, Annelida)
}

\author{
Vincent Rousset ${ }^{a}$, Greg W. Rouse $^{\mathrm{b}}$, Jean-Pierre Féral ${ }^{\mathrm{c}}$, Daniel Desbruyères ${ }^{\mathrm{d} *}$ and Fredrik Pleijel ${ }^{\mathrm{a}}$ \\ aLaboratoire de Biologie des Invertébrés Marins et Malacologie, ESA CNRS 8044, Muséum National d'Histoire \\ Naturelle, 57 rue Cuvier, 75231 Paris Cedex 5, France; Service de Sytématique Moléculaire, Institut de \\ Systématique, CNRS FR 1541, Muséum National d'Histoire Naturelle, 43 rue Cuvier, 75231 Paris Cedex 5, \\ France. \\ ${ }^{\mathrm{b}}$ Marine Invertebrates, South Australian Museum, North Terrace, Adelaide \& Environmental Biology, University of \\ Adelaide, North Terrace, Adelaide, South Australia 5000, Australia. \\ 'Observatoire Océanologique de Banyuls, URA CNRS 117, 66650 Banyuls-Sur-Mer, France. \\ ${ }^{\mathrm{d} D e ́ p a r t e m e n t ~ E n v i r o n n e m e n t ~ P r o f o n d, ~ C e n t r e ~ d e ~ B r e s t ~ d e ~ l ' I F R E M E R, ~ B P 70, ~} 29280$ Plouzané, France \\ *: Corresponding author : daniel.desbruyeres@ifremer.fr
}

\begin{abstract}
In this study we assessed the phylogenetic relationships of the hydrothermal vent polychaete group Alvinellidae, based on parsimony analyses of combined morphological and molecular data. Morphological data were obtained from newly examined specimens and literature information of 16 terminal taxa belonging to Alvinellidae, Ampharetidae, Pectinariidae, Terebellidae, Trichobranchidae, and the outgroups Oweniidae and Sabellidae. Molecular data were based on $28 \mathrm{~S}$ rRNA from 13 of the 16 morphological terminals (10 previously published sequences plus three new ones). The combined analysis indicated the clades ((Alvinellidae, Trichobranchidae) Pectinariidae) and (Ampharetidae, Terebellidae). Alvinellidae, Ampharetidae and Terebellidae, as currently delineated, are monophyletic. The positions of Trichobranchidae and Pectinariidae contradicted traditional views, and they also had low Bremer support and merit further studies. Well-supported clades included Alvinellidae and Terebellinae. Previous statements that Alvinellidae are either nested within Ampharetidae or the sister to this taxon were not supported. The traditional but here contradicted view that Terebellidae and Trichobranchidae are closely related may be based on plesiomorphic similarities between these two taxa.
\end{abstract}

Keywords: phylogenetic, polychaete, Alvinellidae, molecular 


\section{Introduction}

Alvinellidae is a group of tube-dwelling polychaetes known only from hydrothermal vent systems in the Pacific Ocean. Although the discovery of the group is recent (Desbruyères \& Laubier 1980), it has already been subject to a series of studies dealing with taxonomy, ecology, physiology and genetics (see Desbruyères et al., 1998, and references within). Alvinella pompejana Desbruyères \& Laubier, 1980, the "Pompeii worm", represents the first named taxon and was originally referred to a new subfamily Alvinellinae, positioned within Ampharetidae. With the discovery of further taxa belonging to the group, Desbruyères \& Laubier (1986) re-evaluated the relationships to Ampharetidae and referred it to the new family Alvinellidae. Alvinellidae was regarded as having a basal position within a group referred to here as Terebelliformia, including also Ampharetidae, Pectinariidae, Terebellidae and Trichobranchidae. Féral et al., (1994) presented the first phylogenetic analysis of Alvinellidae based on the 28S rRNA gene, indicating that Alvinellidae is monophyletic and positioned within a clade including Terebellidae and Trichobranchidae. More recent phylogenetic analyses, based on morphology, instead indicate that the group is closer to Ampharetidae (Rouse \& Fauchald 1997). Furthermore, a recent review of the literature on Terebelliformia (Rouse 2001) raised the suggestion that Alvinellidae, as originally proposed by Desbruyères \& Laubier (1980) may be nested within the Ampharetidae. Accordingly, this study is designed to answer three questions: (1) Are Alvinellidae and Ampharetidae separate, non-nested taxa (2) Are Alvinellidae and Terebellidae separate and non-nested, and (3) What is the sister group of Alvinellidae?

In order to address these issues, we use previously published sequences of the C1, D1 and C2 (in part) domains of 28S rRNA, we add new sequences for three taxa: Amphisamytha galapagensis Zottoli, 1983, Anobothrus gracilis (Malmgren, 1866) and Pectinaria auricoma (O.F. Müller, 1776), and we combine these data in a parsimony analysis together with morphological data obtained from examined specimens and information from the literature.

\section{Material and methods}

Taxa

The terminal taxa were selected in order to examine the position of the Alvinellidae within the Terebelliformia, and with special consideration to the previous statements that the group is close to or nested within Ampharetidae or Terebellidae (Desbruyères \& Laubier 1980; Féral et al., 1994). Terminals were further chosen in order to span as much as possible of the morphological variation, but were also constrained by availability of sequence data. Examined specimens are detailed in Table 1. 
Table 1 List of specimens examined for each terminal taxon included in the analysis. Abrreviations: IFREMER (Institut Français pour l'Exploitation de la Mer), MNHN (Muséum national d'Histoire naturelle, France), NMW (National Museum of Wales), WHOI (Woods Hole Oceanographic Institution).

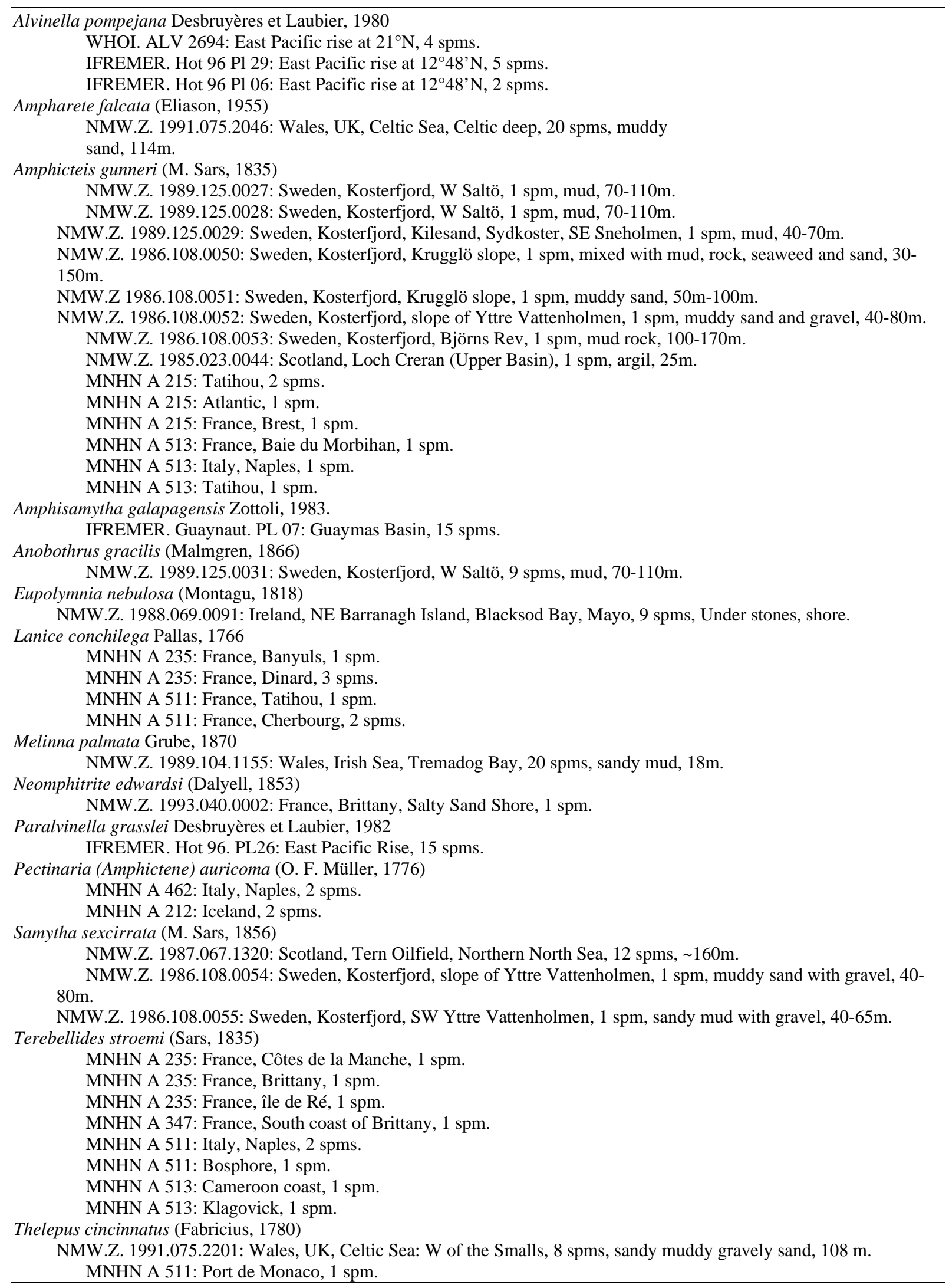


Molecular characters

The 11 previously published sequences (Féral et al., 1994), correspond to domains C1, D1 and (in part) C2, and the three new unpublished sequences of Amphysamytha galapagensis, Anobothrus gracilis and Pectinaria auricoma to domain D1 of the 5' end of 28S rRNA gene. The sequence for A. galapagensis was obtained using the procedure described in Féral et al., (1994), the others are detailed below. The three new sequences are deposited at GenBank under accession numbers AF501669 for A. galapagensis, AF501670 for A. gracilis, and AF501668 for P. auricoma.

\section{Amplification and sequences}

Total genomic DNA was extracted from ethanol preserved specimens using a modified hexadecyl-trimethyl-ammonium bromide (CTAB) protocol (Winnepenninckx et al., 1993). Domain D1 of 28S rRNA gene of Anobothrus and Pectinaria were amplified using the universal primers of C1': 5'- ACCCGCTGAATTTAAGCAT-3' (forward) and C2: 5'TGAACTCTCTCTTCAAAGTTCTTTTC-3' (reverse). Each $50 \mu \mathrm{l}$ reaction consisted of 0,3 $\mu \mathrm{g}$ of template DNA, with (final concentrations) 5\% DMSO, $0.165 \mathrm{mM}$ each dNTP, $1.5 \mathrm{U}$ Qbiotaq polymerase (Qbiogen Inc.), $20 \mathrm{mM}$ Tris-HCl, $16 \mathrm{mM}\left(\mathrm{NH}_{4}\right)_{2} \mathrm{SO}_{4}, 2.5 \mathrm{mM} \mathrm{MgCl}$, 30 $\mathrm{p} M$ of each primer. Following initial denaturation at $94{ }^{\circ} \mathrm{C}$ for $4 \mathrm{~min}$, samples were amplified in 35 cycles: 40 s at $94{ }^{\circ} \mathrm{C}, 40 \mathrm{~s}$ at $48{ }^{\circ} \mathrm{C}$ and 40 s at $72{ }^{\circ} \mathrm{C}$. Double-stranded DNA products, purified using MinElute gel extraction kit (Qiagen Inc.), were used for direct sequencing with dye-labeled terminators (Beckman, Inc.). Sequencing reactions were performed according to the manufacturer's instructions and labelled fragments were analysed by a CEQ2000 sequencer (Beckman, Inc.). The sequences were assembled and verified using the Sequencher SQA13.1 program (Gene Codes, Inc.). Sequences were aligned using MALIGN (Wheeler \& Gladstein 1994-2000) with the following settings: internal 3; leading 2; trailing 2; changecost 1; randorder 5; arrt; atbr; build; score 2; nogap; keepaligns; keeptrees 10; treerandorders; tbr; interleaved; paup; linelength 60 . The oupout alignment was not further manipulated since it represents the optimal primary homology statements across the taxa, relative to the used criterion (parsimony for MALIGN) and the parameters (gap-change cost ratio). The alignment is available at http://www.mnhn.fr/mnhn/bimm/pleijel_htm. Of the 392 sites, 174 are variable and 108 are parsimony informative.

\section{Morphology}

The morphological data were derived from new observations of external morphology and from literature on internal anatomy which is generally reviewed in Rouse and Pleijel (2001). This resulted in 52 characters. Character numbers in the following descriptions correspond to the character list in Table 2 and the matrix in Table 3. For simplicity we refer to the terminal species by their generic names; this does not imply that the scored characters are uniform across whole genera. 
Table 2 Characters used in the parsimony analyses.

1. Prostomium: 0. Hood-like; 1 . Ridge-shaped; 2 . Crown

2. Peristomium: 0. Ring; 1 . With extend upper and lower lips

3. Retractile tentacles: 0 . Absent; 1 . Present

4. Origin of tentacles: 0 . Outside mooth; 1 . Inside mouth

5. Specialised sex tentacles: 0. Absent; 1 . Present

6. Lateral lobes: 0. Absent; 1 . Present

7. Segmental branchiae: 0. Absent; 1. Present

8. Branchial membrane: 0. Absent; 1. Present

9. Arrangement of branchiae: 0. Segmentally arranged; 1 . Grouped on single anterior segment

10. Branchiae: 0. Digitate; 1. Branching

11. Branchial lamellae: 0 . Absent; 1. Present

12. Branchial trunk: 0. Smooth; 1 . With annulated surface

13. Branchiae on segment 2: 0. Absent; 1 . Present

14. Branchiae on segment 3: 0. Absent; 1 . Present

15. Branchiae on segment 4: 0. Absent; 1. Present

16. Branchiae on segment 5: 0. Absent; 1 . Present

17. Segmental organ funnel in segment 2: 0 . Absent; 1 . Present

18. Segmental organ funnel in segment 3: 0. Absent; 1 . Present

19. Segmental organ funnel in segment 4: 0 . Absent; 1 . Present

20. Segmental organ funnel in segment 5: 0. Absent; 1 . Present

21. Segmental organ funnel in segment 6: 0. Absent; 1 . Present

22. Segmental organ funnel in segment 7: 0 . Absent; 1 . Present

23. Segmental organ funnel in segment 8: 0. Absent; 1 . Present

24. Gular membrane: 0. Absent; 1 . Present

25. Gular membrane between segments 4 and 5: 0. Absent; 1 . Present

26. Thoracic ventral glandular area: 0 . Absent; 1 . Present

27. Thoracic ventral glandular area: 0 . Ventral central pads; 1 . Ventral annullae

28. Notopodial cirri: 0. Absent; 1 . Present

29. Notochaetae on segment 1: 0 . Absent; 1 . Present

30. Notochaetae on segment 2: 0 . Absent; 1 . Present

31. Paleae on segment 2: 0 . Absent; 1 . Present

32. Notochaetae on segment 3: 0 . Absent; 1 . Present

33. Notochaetae on segments 4 and 5: 0. Absent; 1 . Present

34. Straight spines: 0 . Absent; 1 . Present

35. Neurochaetae on segment 3: 0 . Absent; 1 . Present

36. Neurochaetae on segment 4: 0 . Absent; 1 . Present

37. Neurochaetae on segment 5: 0 . Absent; 1 . Present

38. Neurochaetae on segments 6 and 7: 0. Absent; 1 . Present

39. Neurochaetae on segment 8: 0 . Absent; 1 . Present

40. Neurochaetae on segment 9: 0. Absent; 1 . Present

41. Notochaetae on segments 18 and 19: 0. Absent; 1 . Present

42. Notochaetae on segment 20: 0 . Absent; 1 . Present

43. Notochaetae on segments 21-25: 0. Absent; 1 . Present

44. Capillary notochaetae: 0 . Smooth; 1 . Serrated

45. Rows of uncini: 0 . Single; 1 . Double; 2. Multiple

46. Anterior uncini: 0 . Without main fang; 1 . With main fang

47. Teeth of anterior uncini: 0 . In a single row ; 1 . In multiple rows; 2 . Dispersed; 3 . Two teeth

48. Handles of anterior uncini: 0 . Short; 1 . Long

49. Posterior neuropodial tori: 0. Low; 1 . Distinct lobes

50. Pygidial cirri: 0. Absent; 1. Present

51. Lateral organs: 0. Absent; 1. Present

52. Heart body: 0. Absent; 1. Present 
Table 3 Character matrix. Owenia and Perkinsiana are outgroups. ‘?’ indicates inapplicable or uncertain information.

\begin{tabular}{|c|c|c|c|c|c|c|}
\hline & $\begin{array}{l}1 \\
1234567890\end{array}$ & $\begin{array}{l}2 \\
1234567890\end{array}$ & $\begin{array}{l}3 \\
1234567890\end{array}$ & $\begin{array}{l}4 \\
1234567890\end{array}$ & $\begin{array}{l}5 \\
1234567890\end{array}$ & 12 \\
\hline Owenia fusiformis & 200?०००??? & ??????०००० & $100000 ? 011$ & 0110011111 & 1111203100 & 00 \\
\hline Perkinsiana antarctica & 200?०००??? & ???????००० & $000000 ? 011$ & 0110111111 & 1110012100 & $0 \odot$ \\
\hline Alvinella pompejana & 0011101010 & 111111???? & ???11??000 & $? 111000000$ & 1111000000 & $? 1$ \\
\hline Ampharete falcata & 0011001110 & 011111???? & ?????11101 & 1010000111 & 0000001011 & 1? \\
\hline Amphicteis gunneri & 0011001110 & 0111110111 & 1001111101 & 1110000111 & 1000000011 & 01 \\
\hline Amphisamytha galapagensis & $0011001 ? 10$ & 011111???? & ?????11000 & $? 110000111$ & 1000000010 & $? 1$ \\
\hline Anobothrus gracilis & 0011001110 & 011111???? & ???1111001 & 1110000111 & 0000001010 & $? ?$ \\
\hline Eupolymnia nebulosa & 1110011001 & 0011101111 & 1101110000 & $? 010001111$ & 1100112010 & 01 \\
\hline Lanice conchilega & 1110011001 & 0011101111 & 1111110000 & $? 010001111$ & 1100112010 & 01 \\
\hline Melinna palmata & 0011001110 & 0111110011 & 1101111000 & $? 110110111$ & 1000000010 & 01 \\
\hline Neoamphitrite edwardsi & 1110011001 & 001110???? & ?????10००९ & $? 010001111$ & 1101112010 & ○? \\
\hline Paralvinella grasslei & 0011101010 & 0111110??? & ???11??100 & $? 111000000$ & 1110000000 & $? 1$ \\
\hline Pectinaria auricoma & ??1?001000 & 1100110100 & $1101 ? 1 ? 001$ & 1000000001 & 1100001010 & 11 \\
\hline Samytha sexcirrata & 0011001110 & 0111110111 & $\odot \odot \odot 11110 \odot \odot$ & $? 110000111$ & 1000001011 & $? ?$ \\
\hline Terebellides stroemi & $111000100 ?$ & 1111001000 & 1101111000 & $? 010000011$ & $1000 \odot 12110$ & 01 \\
\hline Thelepus cincinnatus & 1110001000 & 0011000111 & 1001110000 & ?110001111 & 1110012010 & Q? \\
\hline
\end{tabular}

(1). Prostomium. In Alvinella, Ampharete, Amphicteis, Amphisamytha, Anobothrus, Melinna, Paralvinella and Samytha the prostomium appears as a hood situated over the buccal region (e.g., Holthe 1986a: figs 18a and 21a; see also Rouse 2001a, b). The nature of the head in Terebellidae (including Trichobranchidae) is not yet fully resolved (see Rouse 2001c). We interpreted Eupolymnia, Lanice, Neoamphitrite, Terebellides and Thelepus as having prostomial ridge, since the upper lip has been shown by Heimler (1983) to be of peristomial origin. In Pectinaria the fusion of the prostomium, the peristomium and the anterior segments (Thorson 1946) did not permit assessment of the prostomial delineation and shape, and is therefore scored as unknown. Similarities of the tentacular crown in Oweniidae and Sabellida in early developmental stages (Thiébaut \& Dauvin 1992) indicate that they may be homologous features, although adult stages exhibit a number of differences (e.g., Gardiner 1978); we here treat them as homologues, but the issue certainly warrants further study.

(2). Peristomium. The peristomium in Alvinellidae was interpreted by Rouse \& Fauchald (1997) as the roof of the mouth, including perhaps also the lower lip. Rouse (2001a), however, indicated that it has been misinterpreted and argued that Alvinellidae have a peristomium which is clearly demarcated from the prostomium, and forms a ventrally visible ring in adults (see also Zal et al., (1994): fig 1A and B). Rouse (2001b) also reinterpreted the head region and the most anterior segments of Ampharetidae, and argued that the peristomium is a ring, in agreement with some previous authors (Day 1961; Fauvel 1927). Our observations of juvenile and adult specimens confirm that Alvinella, Ampharete, Amphicteis, Amphisamytha, Anobothrus, Melinna, Paralvinella and Samytha, as well as the outgroups, have a peristomium that forms a ring. In Eupolymnia, Lanice, Neoamphitrite, Terebellides and Thelepus, we follow the interpretation of Heimler (1983), stating that the peristomium forms the upper and lower lips. Pectinaria was scored with a question mark, since the fusion of the peristomium with the prostomium in adult specimens does not permit clear assessment of this feature. 
Figure 1 A-D. Terbelliformia relationships based on different analyses. Abbreviations in bold indicate family affinity of terminals. $-A$. The most-parsimonious tree based on 28S rRNA data. $-B$. Strict consensus of the 36 most-parsimonious trees based on morphological data. A, B. Numerals represent Bremer support values. $-C$. One out of four most-parsimonious trees based on the combined data. $-D$. Strict consensus tree based on the four most-parsimonious trees from the combined data; numerals represent Bremer values.

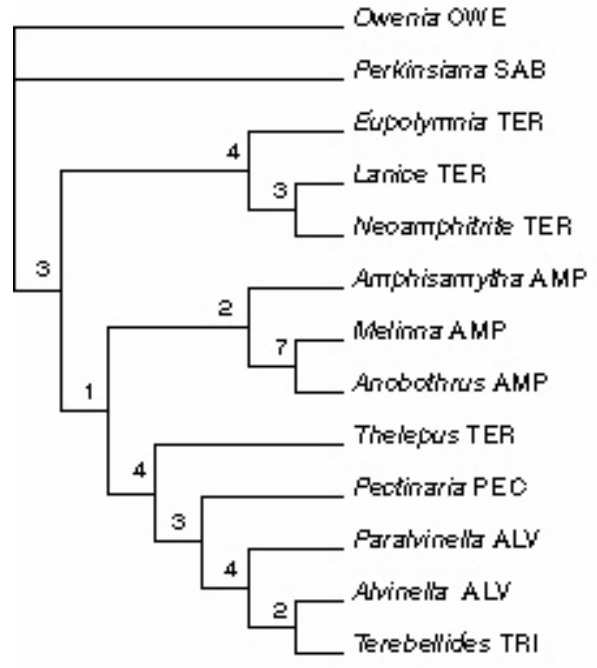

A

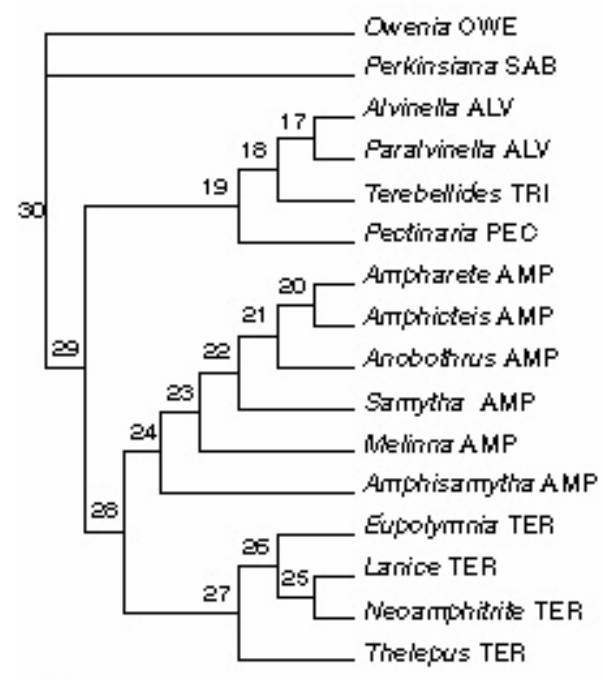

C

(3). Retractile tentacles. The tentacles (= multiple grooved palps) are retractile (i.e., of variable length) in all terminals except the two outgroups (see next character regarding homology of multiple grooved palps).

(4). Origin of tentacles. The tentacles are situated externally on the upper lips in Eupolymnia, Lanice, Neoamphitrite, Terebellides and Thelepus, and they originate from the inside of the mouth in Alvinella, Ampharete, Amphicteis, Amphisamytha, Anobothrus, Melinna, Paralvinella and Samytha. Pectinaria and the two outgroups were scored with question marks due to lack of information (note also that Orrhage (2001) reinterpreted the multiple, grooved 
palps in a series of Ampharetidae, Pectinariidae and Terebellidae, and regarded them as nonhomologous to palps in other polychaetes).

(5). Specialised sex tentacles. Present in Alvinella and Paralvinella (see e.g., Zal et al., 1994: fig. 1a); absent in all other terminals (note, however, that tentacle dimorphism is present in some Ampharetidae not included in this study; see Rouse 2001b).

(6). Lateral lobes. Present in Eupolymnia, Lanice and Neoamphitrite; absent in remaining taxa.

(7). Segmental branchiae. Present in all terminals except the two outgroups.

(8). Branchial membrane. A membrane which units the basal part of the branchiae is present in Ampharete, Amphicteis, Anobothrus, Melinna and Samytha; uncertain for Amphisamytha. The character is inapplicable for the two outgroups and absent in remaining taxa.

(9). Arrangement of branchiae. This character refers to the position of branchiae in adult specimens. Due to branchial migration during early ontogeny the branchiae appear on a single anterior segment in adults of Alvinella, Ampharete, Amphicteis, Amphisamytha, Anobothrus, Melinna, Paralvinella and Samytha (e.g., Desbruyères \& Laubier 1986: fig 7b and c; Holthe 1986a: figs 10a and 18e). The other ingroup taxa have segmentally arranged branchiae, and the outgroups are scored as inapplicable since they lack corresponding branchiae.

(10). Branchiae. Branchiae are digitate in Alvinella, Ampharete, Amphicteis, Amphisamytha, Anobothrus, Melinna, Paralvinella, Pectinaria, Samytha and Thelepus. We scored Alvinellidae as having digitate branchiae like many Ampharetidae, with the branchiae interpreted as having a similar main trunk with additional, secondary structures: two series of lamellae in Alvinella (Desbruyères \& Laubier 1980: fig. 3), or multiple rows of simple unbranched filaments in Paralvinella (Desbruyères \& Laubier 1982: fig. 2c). These lamellae and filaments constitute autapomorphies and were excluded. Branching branchiae occur in Eupolymnia, Lanice and Neoamphitrite. Terebellides was scored with a question mark due to difficulties to interprete the particular shape of the branchiae. The character is inapplicable for the outgroups.

(11). Branchial lamellae. Present in Alvinella (Desbruyères \& Laubier 1980: fig. 3), Pectinaria and Terebellides (Beesley et al., 2000: fig 1.124a and d); absent from other ingroup taxa and inapplicable in the outgroups.

(12). Branchial trunk. This character is based on previously unreported observations of the surface of branchial trunks. In Eupolymnia, Lanice, Neoamphitrite and Thelepus the surface of the branchial trunk is smooth, whereas it in all other ingroup taxa is provided with surface annulations. The character is inapplicable for the outgroups.

(13-16). Presence of branchiae on anterior segments. The position of branchiae in Alvinellidae have been variously interpreted in the literature. In Alvinella, they were initially described as appearing from a single achaetous segment (Desbruyères \& Laubier 1980), whereas in Paralvinella grasslei they were described (Desbruyères \& Laubier 1982) as appearing on the first four segments. Later, Desbruyères \& Laubier (1986) reinterpreted the anterior segmentation in Alvinella, inferring a fusion of the anterior segments and instead referring the branchiae to segments 1-4. Subsequently, the presence of a prebranchial segment was suggested by Desbruyères \& Laubier (1989), whereby the branchiae in all Alvinellidae were referred to segments 2-5, an interpretation which is in agreement with descriptions of juvenile Paralvinella by Zal et al., (1995) and Desbruyères \& Laubier (1986: figs 24, 25). Desbruyères \& Laubier (1991) inferred the existence of three additional segments fused with segment 2 in Alvinella, and so are not visible. This implies that in Alvinella, unlike Paralvinella, there are five achaetous anterior segments, not two. Based on Desbruyères \& Laubier's (1991) interpretation, both the branchiae and the stout notopodial spines in adult Alvinella and Paralvinella are situated on corresponding segments. This allows for a positional homology of the modified notopodial spines in Alvinella and Paralvinella, which 
then appear on segments 9 and 10 in the former and 9 in the latter. On the other hand, the first notochaetae will under this interpretation appear on different segments in the two taxa. We here suggest an alternative interpretation (see also Rouse 2001a), which invokes, not fusion of branchial segments, but branchial migration during the early ontogeny. Following the studies of the circulatory system in Alvinellidae by Jouin-Toulmond et al., (1996), there is no indication of segmental fusion in Alvinella; furthermore the presence of branchial migration would be in agreement with many Ampharetidae. Based on this, we interpreted all Alvinellidae as having two anterior achaetous segments and branchiae present on segments 25. This means that notochaetae appear from segment 3, but notopodial spines are present on segments 6 and 7 in Alvinella and 9 in Paralvinella (note: one of the authors, DD, disagrees ; however, trial analyses indicate that it has little impact on the tree topologies). Rouse (2001b) also proposed an alternative segmental enumeration in Ampharetidae, with a single achaetous segment in anterior to the branchial/chaetal segment. What was referred to as "buccal segment" by Fauvel (1896, 1927) and Day (1964), constitutes the peristomium. This interpretation is accepted here, and the branchiae in Ampharete, Amphicteis, Amphisamytha, Anobothrus, Melinna and Samytha are scored as present on segments 2-5.

For Terebellidae, we follow the classic interpretation (e.g., Fauvel 1927; Holthe 1986a) in which there is a single achaetous segment anterior to the branchial segment. Accordingly there are three pairs of branchiae situated on segments 2-4 in Eupolymnia, Lanice, Neoamphitrite and two pairs situated on segments 2-3 in Thelepus. Recently, Orrhage (2001) re-investigated the anatomy of the central nervous system of some Terebelliformia, including Pectinaria. According to this study, the paleae and the first pair of lateral cirri of Pectinaria are situated on segment 2, the second pair of lateral cirri on segment 3 , and the two pairs of branchiae on segments 4-5. His interpretation is followed in this study, (and differs from that of Rouse 2001d), and Pectinaria thus has two pairs of branchiae on segments 4 and 5. In Terebellides, there are two pairs of branchiae situated on segments 2 and 3 . The character is inapplicable for the two outgroups. We summarize the information relating to our interpretation of anterior segmental characters in Table 4.

(17-23). Segmental organ funnels in segments 2-8. The distribution of segmental organs in polychaetes varies, but a common pattern is represented by presence along most of the body (e.g., most Aciculata). In other polychaete groups, such as Ampharetidae and Terebellidae, there are a few pairs of segmental organs in the anterior part of the body only (Table 4). Owing to the anterior complete diaphragm (see below), one or more of these anterior pairs of segmental organs are excretory, and the posterior ones act as gonoducts (Rouse \& Pleijel, 2001). Here we identify the internal positions of the funnels rather than the positions of the exit pores. The segmental organs of Alvinellidae are not well known. They have only been studied in detail for Paralvinella grasslei, where there are two pairs anteriorly (Zal et al., 1994), but their location was not clearly delineated. Hessle (1917) found that there are never more than five pairs of segmental organs in Ampharetidae. The anteriormost pair usually has funnels lying in segment 4 (i.e., anterior to the diaphragm) and opening to the exterior in segment 4 (Anobothrus, Ampharete), or 5 (Melinna). In some taxa (Amphisamytha, Amphicteis, Samytha) there are two pairs of segmental organs with funnels anterior to the gular membrane. Details of segmental organ distribution are not available for Ampharete falcata and Amphisamytha galapagensis. Hessle (1917) found that Terebellidae and Trichobranchidae have between three and seven pairs of segmental organs in the anterior part of the body, and justifications for the scoring of Eupolymnia nebulosa, Lanice conchilega, Thelepus cincinnatus and Terebellides stroemi can be found in that paper. Details for segmental organ distribution are not available for Neoamphitrite edwardsi and they are scored as unknown. The distribution of segmental organs in Pectinariidae is well known following Hessle's (1917) detailed study. The first pair is presumably excretory only. They have funnels 
anterior to the diaphragm in segment 3 and exit from the body on segment 4 . In Pectinaria there are also segmental organ funnels in segments 4, 7 and 8, but are absent from segments 5 and 6. The information is summarized in Table 4.

Table 4 Morphological alignment of segments 1-10. Abbreviations: A - Acicular, B - Branchiae, C- Capillary, F - Segmental organ funnel, Ne - Neurochaetae, No - Notochaetae, Pa - Palae, Sp - Spines, U - uncini, P - Present.

\begin{tabular}{|c|c|c|c|c|c|c|c|c|c|c|}
\hline Species & Seg. 1 & Seg. 2 & Seg. 3 & Seg. 4 & Seg. 5 & Seg. 6 & Seg. 7 & Seg. 8 & Seg. 9 & Seg. 10 \\
\hline \multirow[t]{4}{*}{ O. fusiformis } & $\mathrm{B}=0$ & $\mathrm{~B}=0$ & $\mathrm{~B}=0$ & $\mathrm{~B}=0$ & $\mathrm{~B}=0$ & $\mathrm{~B}=0$ & $\mathrm{~B}=0$ & $\mathrm{~B}=0$ & $\mathrm{~B}=0$ & $\mathrm{~B}=0$ \\
\hline & No $=C$ & $\mathrm{No}=\mathrm{C}$ & $\mathrm{No}=\mathrm{C}$ & No $=C$ & $\mathrm{No}=\mathrm{C}$ & No $=C$ & No $=C$ & No $=C$ & No $=C$ & No $=C$ \\
\hline & $\mathrm{Ne}=0$ & $\mathrm{Ne}=0$ & $\mathrm{Ne}=0$ & $\mathrm{Ne}=\mathrm{U}$ & $\mathrm{Ne}=\mathrm{U}$ & $\mathrm{Ne}=\mathrm{U}$ & $\mathrm{Ne}=\mathrm{U}$ & $\mathrm{Ne}=\mathrm{U}$ & $\mathrm{Ne}=\mathrm{U}$ & $\mathrm{Ne}=\mathrm{U}$ \\
\hline & $\mathrm{F}=0$ & $F=0$ & $\mathrm{~F}=0$ & $\mathrm{~F}=0$ & $F=0$ & $\mathrm{~F}=\mathrm{P}$ & $\mathrm{F}=0$ & $F=0$ & $\mathrm{~F}=0$ & $\mathrm{~F}=0$ \\
\hline \multirow[t]{4}{*}{ P. antarctica } & $B=0$ & $B=0$ & $\mathrm{~B}=0$ & $\mathrm{~B}=0$ & $\mathrm{~B}=0$ & $\mathrm{~B}=0$ & $\mathrm{~B}=0$ & $\mathrm{~B}=0$ & $B=0$ & $\mathrm{~B}=0$ \\
\hline & No $=\mathrm{C}$ & $\mathrm{No}=\mathrm{C}$ & No $=C$ & No $=C$ & No $=\mathrm{C}$ & No $=\mathrm{C}$ & No $=C$ & No $=\mathrm{C}$ & No $=U$ & $\mathrm{No}=\mathrm{U}$ \\
\hline & $\mathrm{Ne}=0$ & $\mathrm{Ne}=\mathrm{U}$ & $\mathrm{Ne}=\mathrm{U}$ & $\mathrm{Ne}=\mathrm{U}$ & $\mathrm{Ne}=\mathrm{U}$ & $\mathrm{Ne}=\mathrm{U}$ & $\mathrm{Ne}=\mathrm{U}$ & $\mathrm{Ne}=\mathrm{U}$ & $\mathrm{Ne}=\mathrm{C}$ & $\mathrm{Ne}=\mathrm{C}$ \\
\hline & $\mathrm{F}=?$ & $\mathrm{~F}=?$ & $\mathrm{~F}=0$ & $\mathrm{~F}=0$ & $\mathrm{~F}=0$ & $\mathrm{~F}=0$ & $\mathrm{~F}=0$ & $\mathrm{~F}=0$ & $\mathrm{~F}=0$ & $F=0$ \\
\hline \multirow[t]{4}{*}{ A. pompejana } & $\mathrm{B}=0$ & $\mathrm{~B}=\mathrm{P}$ & $\mathrm{B}=\mathrm{P}^{1}$ & $\mathrm{~B}=\mathrm{P}^{1}$ & $\mathrm{~B}=\mathrm{P}^{1}$ & $\mathrm{~B}=0$ & $\mathrm{~B}=0$ & $\mathrm{~B}=0$ & $\mathrm{~B}=0$ & $\mathrm{~B}=0$ \\
\hline & No $=0$ & No $=0$ & $\mathrm{No}=\mathrm{C}$ & No $=\mathrm{C}$ & $\mathrm{No}=\mathrm{C}$ & $\mathrm{No}=\mathrm{Sp}$ & $\mathrm{No}=\mathrm{Sp}$ & No $=\mathrm{C}$ & No $=C$ & No $=C$ \\
\hline & $\mathrm{Ne}=0$ & $\mathrm{Ne}=0$ & $\mathrm{Ne}=0$ & $\mathrm{Ne}=0$ & $\mathrm{Ne}=0$ & $\mathrm{Ne}=0$ & $\mathrm{Ne}=0$ & $\mathrm{Ne}=0$ & $\mathrm{Ne}=0$ & $\mathrm{Ne}=\mathrm{U}$ \\
\hline & $\mathrm{F}=?$ & $\mathrm{~F}=?$ & $\mathrm{~F}=$ ? & $\mathrm{F}=?$ & $\mathrm{~F}=$ ? & $\mathrm{F}=?$ & $\mathrm{~F}=$ ? & $\mathrm{F}=$ ? & $\mathrm{F}=?$ & $\mathrm{~F}=$ ? \\
\hline \multirow[t]{4}{*}{ A. falcata } & $B=0$ & $\mathrm{~B}=\mathrm{P}$ & $\mathrm{B}=\mathrm{P}$ & $\mathrm{B}=\mathrm{P}$ & $\mathrm{B}=\mathrm{P}$ & $\mathrm{B}=0$ & $\mathrm{~B}=0$ & $\mathrm{~B}=0$ & $\mathrm{~B}=0$ & $\mathrm{~B}=0$ \\
\hline & No $=0$ & $\mathrm{No}=\mathrm{Pa}$ & $\mathrm{No}=0$ & $\mathrm{No}=\mathrm{C}$ & $\mathrm{No}=\mathrm{C}$ & No $=\mathrm{C}$ & $\mathrm{No}=\mathrm{C}$ & No $=\mathrm{C}$ & No $=\mathrm{C}$ & No $=\mathrm{C}$ \\
\hline & $\mathrm{Ne}=0$ & $\mathrm{Ne}=0$ & $\mathrm{Ne}=0$ & $\mathrm{Ne}=0$ & $\mathrm{Ne}=0$ & $\mathrm{Ne}=\mathrm{U}$ & $\mathrm{Ne}=\mathrm{U}$ & $\mathrm{Ne}=\mathrm{U}$ & $\mathrm{Ne}=\mathrm{U}$ & $\mathrm{Ne}=\mathrm{U}$ \\
\hline & $\mathrm{F}=?$ & $\mathrm{~F}=$ ? & $\mathrm{F}=?$ & $\mathrm{~F}=?$ & $\mathrm{~F}=$ ? & $\mathrm{F}=?$ & $\mathrm{~F}=?$ & $\mathrm{~F}=?$ & $\mathrm{~F}=$ ? & $\mathrm{F}=?$ \\
\hline \multirow[t]{4}{*}{ A. gunneri } & $\mathrm{B}=0$ & $\mathrm{~B}=\mathrm{P}$ & $\mathrm{B}=\mathrm{P}$ & $\mathrm{B}=\mathrm{P}$ & $\mathrm{B}=\mathrm{P}$ & $\mathrm{B}=0$ & $\mathrm{~B}=0$ & $\mathrm{~B}=0$ & $\mathrm{~B}=0$ & $\mathrm{~B}=0$ \\
\hline & No $=0$ & $\mathrm{No}=\mathrm{Pa}$ & $\mathrm{No}=\mathrm{C}$ & $\mathrm{No}=\mathrm{C}$ & $\mathrm{No}=\mathrm{C}$ & No $=\mathrm{C}$ & No $=\mathrm{C}$ & No $=\mathrm{C}$ & No $=\mathrm{C}$ & No $=\mathrm{C}$ \\
\hline & $\mathrm{Ne}=0$ & $\mathrm{Ne}=0$ & $\mathrm{Ne}=0$ & $\mathrm{Ne}=0$ & $\mathrm{Ne}=0$ & $\mathrm{Ne}=\mathrm{U}$ & $\mathrm{Ne}=\mathrm{U}$ & $\mathrm{Ne}=\mathrm{U}$ & $\mathrm{Ne}=\mathrm{U}$ & $\mathrm{Ne}=\mathrm{U}$ \\
\hline & $F=0$ & $\mathrm{~F}=0$ & $\mathrm{~F}=\mathrm{P}$ & $\mathrm{F}=\mathrm{P}$ & $\mathrm{F}=\mathrm{P}$ & $\mathrm{F}=\mathrm{P}$ & $\mathrm{F}=0$ & $\mathrm{~F}=0$ & $\mathrm{~F}=0$ & $\mathrm{~F}=0$ \\
\hline \multirow[t]{4}{*}{ A. galapagensis } & $\mathrm{B}=0$ & $\mathrm{~B}=\mathrm{P}$ & $\mathrm{B}=\mathrm{P}$ & $\mathrm{B}=\mathrm{P}$ & $\mathrm{B}=\mathrm{P}$ & $\mathrm{B}=0$ & $\mathrm{~B}=0$ & $\mathrm{~B}=0$ & $\mathrm{~B}=0$ & $\mathrm{~B}=0$ \\
\hline & No $=0$ & No $=0$ & No $=\mathrm{C}$ & $\mathrm{No}=\mathrm{C}$ & $\mathrm{No}=\mathrm{C}$ & No $=\mathrm{C}$ & $\mathrm{No}=\mathrm{C}$ & No $=\mathrm{C}$ & No $=\mathrm{C}$ & No $=\mathrm{C}$ \\
\hline & $\mathrm{Ne}=0$ & $\mathrm{Ne}=0$ & $\mathrm{Ne}=0$ & $\mathrm{Ne}=0$ & $\mathrm{Ne}=0$ & $\mathrm{Ne}=\mathrm{U}$ & $\mathrm{Ne}=\mathrm{U}$ & $\mathrm{Ne}=\mathrm{U}$ & $\mathrm{Ne}=\mathrm{U}$ & $\mathrm{Ne}=\mathrm{U}$ \\
\hline & $\mathrm{F}=?$ & $\mathrm{~F}=?$ & $\mathrm{~F}=$ ? & $\mathrm{F}=?$ & $\mathrm{~F}=$ ? & $\mathrm{F}=?$ & $\mathrm{~F}=?$ & $\mathrm{~F}=?$ & $\mathrm{~F}=?$ & $\mathrm{~F}=$ ? \\
\hline \multirow[t]{4}{*}{ A. gracilis } & $\mathrm{B}=0$ & $\mathrm{~B}=\mathrm{P}$ & $\mathrm{B}=\mathrm{P}$ & $\mathrm{B}=\mathrm{P}$ & $\mathrm{B}=\mathrm{P}$ & $\mathrm{B}=0$ & $\mathrm{~B}=0$ & $\mathrm{~B}=0$ & $\mathrm{~B}=0$ & $\mathrm{~B}=0$ \\
\hline & No $=0$ & $\mathrm{No}=\mathrm{Pa}$ & No $=C$ & No $=C$ & $\mathrm{No}=\mathrm{C}$ & $\mathrm{No}=\mathrm{C}$ & No $=C$ & No $=\mathrm{C}$ & No $=C$ & No $=C$ \\
\hline & $\mathrm{Ne}=0$ & $\mathrm{Ne}=0$ & $\mathrm{Ne}=0$ & $\mathrm{Ne}=0$ & $\mathrm{Ne}=0$ & $\mathrm{Ne}=\mathrm{U}$ & $\mathrm{Ne}=\mathrm{U}$ & $\mathrm{Ne}=\mathrm{U}$ & $\mathrm{Ne}=\mathrm{U}$ & $\mathrm{Ne}=\mathrm{U}$ \\
\hline & $\mathrm{F}=?$ & $\mathrm{~F}=?$ & $\mathrm{~F}=$ ? & $\mathrm{F}=$ ? & $\mathrm{F}=$ ? & $\mathrm{F}=?$ & $\mathrm{~F}=$ ? & $\mathrm{F}=$ ? & $\mathrm{F}=$ ? & $\mathrm{F}=$ ? \\
\hline \multirow[t]{4}{*}{ E. nebulosa } & $\mathrm{B}=0$ & $\mathrm{~B}=\mathrm{P}$ & $\mathrm{B}=\mathrm{P}$ & $\mathrm{B}=\mathrm{P}$ & $\mathrm{B}=0$ & $\mathrm{~B}=0$ & $\mathrm{~B}=0$ & $\mathrm{~B}=0$ & $\mathrm{~B}=0$ & $\mathrm{~B}=0$ \\
\hline & No $=0$ & No $=0$ & $\mathrm{No}=0$ & $\mathrm{No}=\mathrm{C}$ & $\mathrm{No}=\mathrm{C}$ & $\mathrm{No}=\mathrm{C}$ & No $=\mathrm{C}$ & No $=\mathrm{C}$ & No $=\mathrm{C}$ & $\mathrm{No}=\mathrm{C}$ \\
\hline & $\mathrm{Ne}=0$ & $\mathrm{Ne}=0$ & $\mathrm{Ne}=0$ & $\mathrm{Ne}=0$ & $\mathrm{Ne}=\mathrm{U}$ & $\mathrm{Ne}=\mathrm{U}$ & $\mathrm{Ne}=\mathrm{U}$ & $\mathrm{Ne}=\mathrm{U}$ & $\mathrm{Ne}=\mathrm{U}$ & $\mathrm{Ne}=\mathrm{U}$ \\
\hline & $\mathrm{F}=0$ & $\mathrm{~F}=\mathrm{P}$ & $\mathrm{F}=\mathrm{P}$ & $\mathrm{F}=\mathrm{P}$ & $F=P$ & $\mathrm{~F}=\mathrm{P}$ & $\mathrm{F}=\mathrm{P}$ & $\mathrm{F}=0$ & $\mathrm{~F}=0$ & $\mathrm{~F}=0$ \\
\hline \multirow[t]{4}{*}{ L. conchilega } & $\mathrm{B}=0$ & $\mathrm{~B}=\mathrm{P}$ & $\mathrm{B}=\mathrm{P}$ & $\mathrm{B}=\mathrm{P}$ & $\mathrm{B}=0$ & $\mathrm{~B}=0$ & $\mathrm{~B}=0$ & $\mathrm{~B}=0$ & $\mathrm{~B}=0$ & $\mathrm{~B}=0$ \\
\hline & No $=0$ & No $=0$ & $\mathrm{No}=0$ & $\mathrm{No}=\mathrm{C}$ & $\mathrm{No}=\mathrm{C}$ & $\mathrm{No}=\mathrm{C}$ & No $=\mathrm{C}$ & $\mathrm{No}=\mathrm{C}$ & No $=\mathrm{C}$ & $\mathrm{No}=\mathrm{C}$ \\
\hline & $\mathrm{Ne}=0$ & $\mathrm{Ne}=0$ & $\mathrm{Ne}=0$ & $\mathrm{Ne}=0$ & $\mathrm{Ne}=\mathrm{U}$ & $\mathrm{Ne}=\mathrm{U}$ & $\mathrm{Ne}=\mathrm{U}$ & $\mathrm{Ne}=\mathrm{U}$ & $\mathrm{Ne}=\mathrm{U}$ & $\mathrm{Ne}=\mathrm{U}$ \\
\hline & $\mathrm{F}=0$ & $\mathrm{~F}=\mathrm{P}$ & $\mathrm{F}=\mathrm{P}$ & $\mathrm{F}=\mathrm{P}$ & $F=P$ & $\mathrm{~F}=\mathrm{P}$ & $\mathrm{F}=\mathrm{P}$ & $\mathrm{F}=\mathrm{P}$ & $\mathrm{F}=0$ & $\mathrm{~F}=0$ \\
\hline \multirow[t]{4}{*}{ M. palmata } & $\mathrm{B}=0$ & $\mathrm{~B}=\mathrm{P}$ & $\mathrm{B}=\mathrm{P}$ & $\mathrm{B}=\mathrm{P}$ & $\mathrm{B}=\mathrm{P}$ & $\mathrm{B}=0$ & $\mathrm{~B}=0$ & $\mathrm{~B}=0$ & $\mathrm{~B}=0$ & $\mathrm{~B}=0$ \\
\hline & No $=0$ & No $=0$ & No $=\mathrm{C}$ & $\mathrm{No}=\mathrm{C}$ & No $=\mathrm{C}$ & No $=\mathrm{C}$ & No $=\mathrm{C}$ & No $=C$ & No $=\mathrm{C}$ & No $=C$ \\
\hline & $\mathrm{Ne}=0$ & $\mathrm{Ne}=0$ & $\mathrm{Ne}=\mathrm{A}$ & $\mathrm{Ne}=\mathrm{A}$ & $\mathrm{Ne}=0$ & $\mathrm{Ne}=\mathrm{U}$ & $\mathrm{Ne}=\mathrm{U}$ & $\mathrm{Ne}=\mathrm{U}$ & $\mathrm{Ne}=\mathrm{U}$ & $\mathrm{Ne}=\mathrm{U}$ \\
\hline & $\mathrm{F}=0$ & $\mathrm{~F}=0$ & $\mathrm{~F}=0$ & $\mathrm{~F}=\mathrm{P}$ & $\mathrm{F}=\mathrm{P}$ & $\mathrm{F}=\mathrm{P}$ & $\mathrm{F}=\mathrm{P}$ & $F=0$ & $\mathrm{~F}=0$ & $F=0$ \\
\hline \multirow[t]{4}{*}{ N. edwardsi } & $\mathrm{B}=0$ & $\mathrm{~B}=\mathrm{P}$ & $\mathrm{B}=\mathrm{P}$ & $\mathrm{B}=\mathrm{P}$ & $\mathrm{B}=0$ & $\mathrm{~B}=0$ & $\mathrm{~B}=0$ & $\mathrm{~B}=0$ & $\mathrm{~B}=0$ & $\mathrm{~B}=0$ \\
\hline & No $=0$ & No $=0$ & No $=0$ & $\mathrm{No}=\mathrm{C}$ & $\mathrm{No}=\mathrm{C}$ & $\mathrm{No}=\mathrm{C}$ & No $=\mathrm{C}$ & No $=\mathrm{C}$ & No $=\mathrm{C}$ & $\mathrm{No}=\mathrm{C}$ \\
\hline & $\mathrm{Ne}=0$ & $\mathrm{Ne}=0$ & $\mathrm{Ne}=0$ & $\mathrm{Ne}=0$ & $\mathrm{Ne}=\mathrm{U}$ & $\mathrm{Ne}=\mathrm{U}$ & $\mathrm{Ne}=\mathrm{U}$ & $\mathrm{Ne}=\mathrm{U}$ & $\mathrm{Ne}=\mathrm{U}$ & $\mathrm{Ne}=\mathrm{U}$ \\
\hline & $\mathrm{F}=?$ & $\mathrm{~F}=?$ & $\mathrm{~F}=?$ & $\mathrm{~F}=?$ & $\mathrm{~F}=$ ? & $\mathrm{F}=?$ & $\mathrm{~F}=?$ & $\mathrm{~F}=?$ & $\mathrm{~F}=?$ & $\mathrm{~F}=?$ \\
\hline P. grassslei & $\mathrm{B}=0$ & $\mathrm{~B}=\mathrm{P}$ & $\mathrm{B}=\mathrm{P}$ & $\mathrm{B}=\mathrm{P}$ & $\mathrm{B}=\mathrm{P}$ & $\mathrm{B}=0$ & $\mathrm{~B}=0$ & $\mathrm{~B}=0$ & $\mathrm{~B}=0$ & $\mathrm{~B}=0$ \\
\hline
\end{tabular}




\begin{tabular}{|c|c|c|c|c|c|c|c|c|c|c|}
\hline & $\begin{array}{l}\mathrm{No}=0 \\
\mathrm{Ne}=0 \\
\mathrm{~F}=0\end{array}$ & $\begin{array}{l}\mathrm{No}=0 \\
\mathrm{Ne}=0 \\
\mathrm{~F}=0\end{array}$ & $\begin{array}{l}\mathrm{No}=\mathrm{C} \\
\mathrm{Ne}=0 \\
\mathrm{~F}=?\end{array}$ & $\begin{array}{l}\mathrm{No}=\mathrm{C} \\
\mathrm{Ne}=0 \\
\mathrm{~F}=?\end{array}$ & $\begin{array}{l}\text { No }=\mathrm{C} \\
\mathrm{Ne}=0 \\
\mathrm{~F}=?\end{array}$ & $\begin{array}{l}\text { No }=\mathrm{C} \\
\mathrm{Ne}=0 \\
\mathrm{~F}=?\end{array}$ & $\begin{array}{l}\text { No }=\mathrm{C} \\
\mathrm{Ne}=0 \\
\mathrm{~F}=?\end{array}$ & $\begin{array}{l}\text { No }=C \\
\mathrm{Ne}=0 \\
\mathrm{~F}=?\end{array}$ & $\begin{array}{l}\mathrm{No}=\mathrm{Sp} \\
\mathrm{Ne}=0 \\
\mathrm{~F}=?\end{array}$ & $\begin{array}{l}\mathrm{No}=\mathrm{C} \\
\mathrm{Ne}=\mathrm{U} \\
\mathrm{F}=?\end{array}$ \\
\hline P. auricoma & $\begin{array}{l}B=0 \\
\text { No }=0 \\
\mathrm{Ne}=0 \\
F=0\end{array}$ & $\begin{array}{l}B=0 \\
\mathrm{No}=\mathrm{Pa} \\
\mathrm{Ne}=0 \\
\mathrm{~F}=0\end{array}$ & $\begin{array}{l}B=0 \\
\text { No }=0 \\
\text { Ne }=0 \\
F=P\end{array}$ & $\begin{array}{l}B=P \\
\text { No }=0 \\
N e=0 \\
F=0\end{array}$ & $\begin{array}{l}B=P \\
N o=0 \\
N e=0 \\
F=0\end{array}$ & $\begin{array}{l}B=0 \\
N o=C \\
N e=0 \\
F=P\end{array}$ & $\begin{array}{l}B=0 \\
N o=C \\
N e=0 \\
F=P\end{array}$ & $\begin{array}{l}B=0 \\
N o=C \\
N e=0 \\
F=0\end{array}$ & $\begin{array}{l}B=0 \\
N o=C \\
N e=U \\
F=0\end{array}$ & $\begin{array}{l}B=0 \\
N o=C \\
N e=U \\
F=0\end{array}$ \\
\hline S. sexcirrata & $\begin{array}{l}B=0 \\
\text { No }=0 \\
\mathrm{Ne}=0 \\
F=0\end{array}$ & $\begin{array}{l}B=P \\
N o=0 \\
N e=0 \\
F=0\end{array}$ & $\begin{array}{l}B=P \\
\text { No }=C \\
N e=0 \\
F=P\end{array}$ & $\begin{array}{l}B=P \\
N o=C \\
N e=0 \\
F=P\end{array}$ & $\begin{array}{l}B=P \\
N o=C \\
N e=0 \\
F=P\end{array}$ & $\begin{array}{l}B=0 \\
N o=C \\
N e=U \\
F=0\end{array}$ & $\begin{array}{l}B=0 \\
N o=C \\
N e=U \\
F=0\end{array}$ & $\begin{array}{l}B=0 \\
N o=C \\
N e=U \\
F=0\end{array}$ & $\begin{array}{l}B=0 \\
N o=C \\
N e=U \\
F=0\end{array}$ & $\begin{array}{l}B=0 \\
N o=C \\
N e=U \\
F=0\end{array}$ \\
\hline T. stroemi & $\begin{array}{l}\mathrm{B}=0 \\
\mathrm{No}=0 \\
\mathrm{Ne}=0 \\
\mathrm{~F}=0\end{array}$ & $\begin{array}{l}B=P \\
\text { No }=0 \\
N e=0 \\
F=P\end{array}$ & $\begin{array}{l}B=P \\
\text { No }=0 \\
\text { Ne }=0 \\
F=0\end{array}$ & $\begin{array}{l}B=0 \\
\text { No }=C \\
N e=0 \\
F=0\end{array}$ & $\begin{array}{l}B=0 \\
\text { No }=C \\
\text { Ne }=0 \\
F=0\end{array}$ & $\begin{array}{l}B=0 \\
\text { No }=C \\
\text { Ne }=0 \\
F=P\end{array}$ & $\begin{array}{l}B=0 \\
N o=C \\
N e=0 \\
F=P\end{array}$ & $\begin{array}{l}B=0 \\
N o=C \\
N e=U \\
F=0\end{array}$ & $\begin{array}{l}B=0 \\
N o=C \\
N e=U \\
F=0\end{array}$ & $\begin{array}{l}B=0 \\
N o=C \\
N e=U \\
F=0\end{array}$ \\
\hline T. cincinnatus & $\begin{array}{l}B=0 \\
\mathrm{No}=0 \\
\mathrm{Ne}=0 \\
F=0\end{array}$ & $\begin{array}{l}B=P \\
\text { No }=0 \\
\text { Ne }=0 \\
F=0\end{array}$ & $\begin{array}{l}B=P \\
N o=C \\
N e=0 \\
F=P\end{array}$ & $\begin{array}{l}B=0 \\
N o=C \\
N e=0 \\
F=P\end{array}$ & $\begin{array}{l}B=0 \\
\text { No }=C \\
\text { Ne }=U \\
F=P\end{array}$ & $\begin{array}{l}B=0 \\
\text { No }=C \\
\text { Ne }=U \\
F=P\end{array}$ & $\begin{array}{l}B=0 \\
N o=C \\
N e=U \\
F=0\end{array}$ & $\begin{array}{l}B=0 \\
\text { No }=C \\
N e=U \\
F=0\end{array}$ & $\begin{array}{l}B=0 \\
\text { No }=C \\
N e=U \\
F=0\end{array}$ & $\begin{array}{l}B=0 \\
N o=C \\
N e=U \\
F=0\end{array}$ \\
\hline
\end{tabular}

${ }^{1}$ Migrating to segment two during ontogeny; see text.

(24-25). Gular membrane. In contrast to most polychaetes, the body cavity of terebelliform individuals lacks distinct septa along most of their body. However, the diaphragm, or gular membrane, is a distinct muscularized septum between two successive anterior segments that divides the coelom into anterior and posterior regions (Rouse \& Pleijel 2001). According to Jouin-Toulmond et al., (1996), this diaphragm separates segments 3 and 4 in Alvinella and segments 4 and 5 in Paralvinella. However, the diaphragm in Alvinella does appear to lie between segments 4 and 5 (A. Zhadan pers. comm.). In Ampharetidae, there is a distinctive diaphragm separating segments 4 and 5, not 5 and 6 as argued by Day (1961). Meyer (1887) regarded this membrane as separating different segments in Ampharetidae and Terebellidae, though this was found to be incorrect by Hessle (1917: 57). Heimler (1983) argued that the diaphragm separates segments 3 and 4 in Terebellidae, but the interpretation adopted here is that Heimler (1983) did not include an additonal segment anterior to the first branchiate segment (see Rouse 2001c). Details for the diaphragm are not available for Ampharete falcata, Amphisamytha galapagensis and Neoamphitrite edwardsi, and they are scored as unknown. According to Hessle (1917), there is a diaphragm separating segments 3 and 4 in Pectinariidae. He states that previous studies (e.g., Fauvel 1897, Meyer 1887) were incorrect in locating the membrane between segments 4 and 5 .

(26-27). Thoracic ventral glandular area. The ventral glandular area has been considered to be absent in Ampharetidae and Trichobranchidae by some authors (e.g., Hessle 1917; Holthe 1986b). From our observations, the thoracic ventral glandular area is present in Ampharete, Amphicteis, Anobothrus, Melinna and Samytha and also Terebellides. This interpretation agrees with Fauvel $(1897,1927)$, who interpreted the thickening made up of epidermal tissue on the anterior segments in Ampharetidae and Trichobranchidae as ventral glandular areas. These areas also occur in the remaining ingroup taxa, except in Alvinella and Paralvinella which were scored with question marks due to uncertain observations. They are absent in outgroups. The thoracic glandular areas, when present, may be subdivided into two different states. In Ampharete, Amphicteis, Anobothrus, Melinna, Samytha (e.g., Holthe 1986a: fig. 9a) and Terebellides (Hartmann-Schröder 1996: fig. 259a), they appear as ventral annullae extended transversally along the segments, whereas in Eupolymnia, Lanice, Neoamphitrite 
and Thelepus they constitute ventral central pads (e.g., Holthe 1986a: fig. 53b). Pectinaria is scored with a question mark due to uncertain observations (see Hartmann-Schröder 1996: fig. 234a).

(28). Notopodial cirri. Present in Ampharete, Amphicteis and Paralvinella; absent in all other terminals.

(29-33). Notochaetae on anterior segments. Scoring of these characters relies on the previously discussed hypothesis relating to the enumeration of the anterior segments.

Notochaetae from segment 1 occur in Owenia and Perkinsiana. According to the enumeration system of Rouse (2001b), paleae in Ampharetidae are situated on segment 2 and are present in Ampharete, Amphicteis and Anobothrus (Table 4). The position of paleae in Pectinaria is uncertain according to Rouse (2001d), but following Orrhage (2001) they originate on segment 2 and thus appear to be homologous to those in some Ampharetidae. Notochaetae on segment 2 are also present in the two outgroups but are absent in all remaining taxa (Table 4). Notochaetae on segment 3 are absent in Ampharete, Eupolymnia, Lanice, Neoamphitrite, Pectinaria and Terebellides, but present in all other taxa; notochaetae on segments 4-5 are only absent in Pectinaria (Table 4).

(34). Straight spines. Present only in the two Alvinellidae terminals. In Alvinella the spines are situated on segment 6 whereas in Paralvinella they are on segment 9. In spite of the difference in position we consider them homologous based on morphological similarity. Spines are absent in remaining taxa (Table 4).

(35-40). Neurochaetae on anterior segments. Following previous enumeration of anterior segments, Perkinsiana have neurochaetae from segment 2, Melinna from segment 3 (except on segment 5 where they are absent), Owenia from segment 4, Eupolymnia, Lanice, Neoamphitrite and Thelepus from segment 5, Ampharete, Amphicteis, Amphisamytha, Anobothrus and Samytha from segment 6, Terebellides from segment 8, Pectinaria from segment 9 and Alvinella and Paralvinella from segment 10 (Table 4).

(41-43). Notochaetae on posterior segments. In Ampharete and Anobothrus, notochaetae are absent after segment 18-19, in Amphicteis, Amphisamytha, Melinna, Samytha and Terebellides after segment 20, and in Eupolymnia, Lanice, Neoamphitrite and Pectinaria after segment 21. In Owenia, Perkinsiana, Alvinella, Paralvinella and Thelepus, notochaetae are present along the entire body (Table 4).

(44). Capillary notochaetae. In Owenia, Alvinella and Neoamphitrite, the capillary notochaetae are serrated whereas they are smooth in all remaining terminals.

(45). Rows of uncini. In Eupolymnia, Lanice and Neoamphitrite there are two rows of uncini (posterior to chaetiger 5); in the remaining terminals there is a single row. In Owenia the uncini occur in multiple rows.

(46). Anterior uncini. In Perkinsiana, Eupolymnia, Lanice, Neoamphitrite, Terebellides and Thelepus, the uncini are provided with a main fang, whereas this is absent in all other terminals.

(47). Teeth of anterior uncini. In Alvinella, Amphicteis, Amphisamytha, Melinna and Paralvinella, the teeth of the uncini are arranged in a single row. Ampharete, Anobothrus, Pectinaria and Samytha have the teeth arranged in multiple rows, and in remaining taxa they are irregularly dispersed. The two teeth in Owenia constitute an autapomorphy.

(48). Handles of anterior uncini. In all terminals except the outgroups and Terebellides, the anterior uncini handles are short.

(49). Posterior neuropodial tori. Alvinella, Paralvinella and the outgroups have low tori, whereas in all other terminals they constitute well-developed lobes.

(50). Pygidial cirri. Pygidial cirri are present only in Ampharete, Amphicteis and Samytha.

(51). Lateral organs. Lateral organs are present in Ampharete and Pectinaria (Nilsson 1912); these organs are absent in Amphicteis, Melinna (Nilsson 1912), Eupolymnia, Lanice, 
Neoamphitrite, Terebellides and Thelepus (Jeener 1928). In the remaining terminals, lateral organs are scored as unknown because of lack of reliable information.

(52). Heart body. In Alvinella, Paralvinella (Jouin-Toulmond et al., 1996), Amphicteis, Amphisamytha (Jouin-Toulmond pers. obs. in Jouin-Toulmond et al., 1996), Eupolymnia, Lanice, Terebellides, Pectinaria (Picton 1899), Melinna (Meyer 1887), a heart body is present; this structure is absent in the two outgroups. For the remaining terminals data are lacking.

\section{Phylogenetic analysis}

Data were entered in MacClade 4.0b10 (Maddison \& Maddison 2001) and parsimony analyses were performed with the branch and bound search algorithm under default settings in PAUP* 4.0b6 (Swofford 1998). Coding of binary characters are either in the form of absent/present, or with both states specified, whereas coding of more complex morphological characters follows "C-coding” as described by Pleijel (1995), where the absence/presence of a feature is treated as one character, and different expressions of the feature are specified in separate, subsidiary characters; taxa lacking the feature are scored as inapplicable in the subsidiary characters. Throughout the analyses, characters were treated as unordered and equally weighted, with gaps and ambiguous nucleotides scored as missing data. TreeRot (Sorensen 1996), together with PAUP (same setting as above), was used for calculation of Bremer support (Bremer 1988). Consistency indices are reported with uninformative characters excluded, and Owenia fusiformis and Perkinsiana antarctica were designated as outgroups.

\section{Results and discussion}

The analysis of C1, D1 and C2 (in part) domains of 28S rRNA data alone (108 parsimony informative characters) yielded a single most parsimonious tree, 416 steps long (Fig. 1a), and with a CI (consistency index) of 0.65 and a RI (retention index) of 0.45 . This tree contains three main clades: Ampharetidae, ((((Alvinella, Terebellides) Paralvinella) Pectinaria) Thelepus) and Terebellinae (i.e. Terebellidae excluding Thelepus). The placement of Terebellides close to Alvinella, supported by a Bremer support value of 2, makes Alvinellidae paraphyletic and is highly unexpected. Another surprising result concerns the status of Terebellidae: owing to the position of Thelepus as sister to (Pectinaria (Paralvinella (Alvinella, Terebellides))), the Terebellidae, in their traditional delimitation, are indicated as being polyphyletic. These two results may represent artefactual responses due the small size of the taxon sampling. Monophyly of Ampharetidae and Terebellinae, respectively, are supported by Bremer support values of 2 and 4, and are more in accordance with the traditional views.

The analysis of the morphological data alone yielded 36 equally parsimonious trees, 89 steps long, with a CI of 0.61 and a RI of 0.74 . A strict consensus tree is illustrated in Fig. 1B. It contains the three main clades (Alvinellidae, Ampharetidae), Terebellinae and (Pectinaria, Terebellides), where Alvinellidae and Terebellinae are the best supported groups with Bremer support values of 4 and 3. This topology agrees with the result of Rouse \& Fauchald (1997) in that Alvinellidae are the sister to Ampharetidae, but this relationship is weakly supported by a Bremer support value of 1 . This tree also indicates an unexpected sister group relationship, supported by a Bremer support value of 1, between Pectinaria (Pectinariidae) and Terebellides (Trichobranchidae). This result contradicts both hypotheses that Trichobranchidae are nested within or sister to Terebellidae. Owing to the basal position of Thelepus, Terebellidae are indicated as being paraphyletic, but the placement of this former taxon is also weakly supported by a Bremer support value of 1 .

The combined molecular and morphological data yielded four equally parsimonious trees, 
516 steps, with a CI of 0.56 , and a RI of 0.52 . One of the most parsimonious trees is illustrated in Fig. 1C, and a strict consensus in Fig. 1D. Note that the four topologies differ only for the resolution within Ampharetidae. Clades with highest support include Alvinellidae and Terebellinae. The monophyly of Alvinellidae is well supported as seen from a Bremer support value of 6 or 19 (ACCTRAN and DELTRAN) apomorphies. Of the eight unequivocally optimized morphological characters, the presence of specialised sex tentacles, the straight spines, and the absence of neurochaetae on segment 9 are unique for the group.

The recovery of a monophyletic Ampharetidae, in its traditional delineation, is perhaps more interesting since the issue has not previously been explicitly addressed. Fauchald \& Rouse (1997) argued for the monophyly of Ampharetidae based on the presence of "retractable palpal tentacles attached to a dorsal curtain". Our examinations of Alvinellidae indicates that the feature is present also in this taxon, and so our results indicate a homoplastic distribution, convergently appearing in both Ampharetidae and Alvinellidae. Ampharetidae is identified by 16 or 17 (ACCTRAN versus DELTRAN) apomorphies. Among the morphological characters, the grouped branchiae, the teeth of anterior uncini in multiple rows, and the loss of notochaetae on segment 20, constitute unambiguous transformations supporting Ampharetidae. Desbruyères \& Laubier (1980) initially referred Alvinellidae to a subfamily within Ampharetidae based on the shared possession of multiple buccal tentacles that can be retracted into the mouth, and the possibility that the group is nested within Ampharetidae was raised also by Rouse (2001a). The results from the combined data refute this possibility and instead indicate that retractable buccal tentacles into the mouth are homoplastic conditions in the two groups. This result is in agreement with the topology of Féral et al., (1994), which shows Alvinellidae and Ampharetidae as non-nested taxa. Using the "constrain tree" option in PAUP* reveals that 13 additional steps are required to include Alvinellidae within Ampharetidae. Similarly, 13 extra steps are required for a constrained sister group relationship between Alvinellidae and Ampharetidae (Rouse \& Fauchald 1997). Instead, a sister group relationship between Alvinellidae and Terebellides (Trichobranchidae) is indicated, a result which certainly is unexpected and appears counter-intuitive but nevertheless has a Bremer support of 4; this relationship warrants further study.

In contrast to the molecular analysis, Terebellidae comes out as monophyletic, and is in agreement with most current literature (see Rouse 2001c and references within). McHugh (1995) also argued for a monophyletic Terebellidae based on the presence of ventral shields, given that they are absent in the outgroup she used, Trichobranchidae. However, our examination of other Terebelliformia indicates that ventral shields have a more general distribution and occurs at least also in Ampharetidae and some Trichobranchidae, possibly also in Pectinariidae and even outside Terebelliformia. Fauchald \& Rouse (1997) considered Terebellidae monophyletic based on "the presence of multiple grooved palps of prostomial origin", but since the tentacles in Ampharetidae and Alvinellidae also are (at least partly) prostomial, this represents another feature that appears to have a more general distribution (see Rouse \& Pleijel 2001). In our combined analysis, the monophyly of Terebellidae is corroborated by a Bremer value of 2, and 16 or 13 (ACCTRAN versus DELTRAN) apomorphies. Of the five unequivocally optimized morphological characters, the smooth surface of branchial trunk and the thoracic centrally postioned ventral pads are unique for the group. In their molecular analysis of 28S rRNA, Féral et al., (1994) showed Alvinellidae as nested within Terebellidae. Our results contradict this hypothesis and instead suggest that Alvinellidae and Terebellidae are separate, non-nested taxa. Nevertheless, the monophyly of Terebellidae warrants further investigation based on more complete taxon sampling, where the positions of Thelepus and closely related taxa deserve special attention.

The results from our combined data go against previous findings with regard to the position of Trichobranchidae, originally erected as Trichobranchinae within Terebellidae by 
Malmgren (1866). It was elevated to family rank by Hessle (1917), who illustrated Trichobranchidae as an explicitly paraphyletic taxon that gave rise to Ampharetidae and Terebellidae. Hessle (1917) proposed that Terebellidae was sister to Terebellides because of their similar digestive system. Subsequent authors tended to place Trichobranchidae within Terebellidae (as Trichobranchinae), though viewing them as a primitive group (e.g., Fauvel 1927, Day 1967). Recent treatments have either placed them outside Terebellidae (McHugh 1995, Fauchald 1977, Fauchald \& Rouse 1997, Hutchings \& Peart 2000), or situated within Terebellidae (Féral et al., 1994, Rouse 2001c). Our results support the separation of Terebellidae and Trichobranchidae, with Trichobranchidae as sister to Alvinellidae. Although possibly counter-intuitive, it could have a basis in that the Terebellidae-Trichobranchidae similarities are plesiomorphic. Further taxon sampling within Trichobranchidae is worthwhile in order to properly assess Hessle's (1917) proposition that Trichobranchidae may in fact be a paraphyletic group that should contain taxa such as Alvinellidae, Ampharetidae and Terebellidae.

Rouse and Fauchald (1997) in their morphological analyses consistently found Pectinariidae to be sister to a clade formed by Ampharetidae and Alvinellidae. Our analysis instead shows that Pectinariidae is sister to a clade formed by Trichobranchidae and Alvinellidae, supported by a Bremer value of 4 (Fig. 1D). The (Pectinariidae (Trichobranchidae, Alvinellidae)) clade is identified by 22 or 15 (ACCTRAN versus DELTRAN) apomorphies, including only one unequivocally optimized morphological character which is the loss of neurochaetae on segments 6 and 7. We consider that more observations are required to have confidence in the placement of this taxon. The placement of Sabellariidae, a taxon that shows some marked similarities to Pectinariidae in the anterior end and in the metamorphosis of the larva (Rouse 2001d), also should be assessed in this context.

Understanding relationships within Terebelliformia is complicated by the different interpretations of anterior segmentation which occur in the literature. Although detailed anatomical information is available for a number of taxa, comparisons across these studies is far from straightforward, since different authors have interpreted prostomium, peristomium and anterior segments differently, and also because they were not always explicit and coherent. Further, combining anatomical information, such as position of funnels and gular membranes, with outer morphology suffers from similar problems due to problems with consistent enumeration of the segments. Our study clearly indicate the need of further anatomical studies of adults, and of information from the larval development and early ontogeny.

\section{Conclusions}

Use of all currently available data (C1, D1 and part of C2 domains of 28S rRNA and 52 morphological characters) indicates that: (1) Alvinellidae and Ampharetidae are non-nested taxa, (2) Alvinellidae and Terebellidae are non-nested taxa, (3) Trichobranchidae is separate from Terebellidae and may be the sister group of Alvinellidae, and (4) Ampharetidae and Terebellidae are monophyletic but require further attention.

\section{Acknowledgements}

We wish to thank Andy Mackie (NMW) for loan of specimens, Anna Zhadan for information on Alvinella, and Thomas Dahlgren and an anonymous referee (with viewpoints very similar to those of Kirk Fitzhugh) for comments which helped to improve the manuscript. Sequencing was carried out at "Service de Systématique Moléculaire", MNHN, with the assistance of Annie Tillier. G.W. Rouse was supported by an Australian Research Council QEII Research Fellowship. 


\section{References}

Beesley, P. L., Ross, G. J. B. \& Glasby, C. J. 2000. Polychaetes \& allies: the southern synthesis. Melbourne: CSIRO Publishing. 465 pp.

Bremer, K. (1988). The limits of amino acid sequence data in angiosperm phylogenetic reconstruction. Evolution, 42, 795-803.

Day, J. H. (1961). The polychaete fauna of South Africa, Part 6. Sedentary species dredged off Cape coasts with a few new records from the shore. Journal of the Linnean Society of London (Zoology), 44, 463-560.

Day, J. H. (1964). A review of the family Ampharetidae (Polychaeta). Annals of the South African Museum, 48, 97-120.

Day, J. H. (1967). A monograph on the Polychaeta of southern Africa. Part 2. Sedentaria. London: Trustees of the British Museum (Natural History).

Desbruyères, D., Chevaldonne, P., Alayse, A. M., Jollivet, D., Lallier, F. H., Jouin-Toulmond, C., Zal, F., Sarradin, P. M., Cosson, R., Caprais, J. C., Arndt, C., Obrien, J., Guezennec, J., Hourdez, S., Riso, R., Gaill, F., Laubier, L. \& Toulmond, A. (1998). Biology and ecology of the 'Pompeii worm' (Alvinella pompejana Desbruyères and Laubier), a normal dweller of an extreme deep-sea environment: A synthesis of current knowledge and recent developments. Deep-Sea Research Part II-Topical Studies in Oceanography, 45, 383-422.

Desbruyères, D. \& Laubier, L. (1980). Alvinella pompejana gen. sp. nov., Ampharetidae aberrant des sources hydrothermales de la ride Est-Pacifique. Oceanologica Acta, 3, 267274.

Desbruyères, D. \& Laubier, L. (1982). Paralvinella grasslei, new genus, new species of Alvinellinae (Polychaeta: Ampharetidae) from the Galapagos rift geothermal vents. Proceedings of the Biological Society of Washington, 95, 484-494.

Desbruyères, D. \& Laubier, L. (1986). Les Alvinellidae, une famille nouvelle d'annélides polychètes inféodées aux sources hydrothermales sous-marines: systématique, biologie et écologie. Canadian Journal of Zoology, 64, 2227-2245.

Desbruyères, D. \& Laubier, L. (1989). Paralvinella hessleri, new species of Alvinellidae (Polychaeta) from the Mariana Back-Arc Basin hydrothermal vents. Proceedings of the Biological Society of Washington, 102, 761-767.

Desbruyères, D. \& Laubier, L. (1991). Systematics, phylogeny, ecology and distribution of the Alvinellidae (Polychaeta) from deep-sea hydrothermal vents. Ophelia Proceedings of the 2nd international polychaete conference supplement 5 (Systematics, Biology and Morphology of World Polychaeta), 31-45.

Fauchald, K. (1977). The polychaete worms. Definitions and keys to the orders, families and genera. Natural History Museum of Los Angeles County. Science Series, 28, 1-188.

Fauchald, K. \& Rouse, G. W. (1997). Polychaete systematics: past and present. Zoologica Scripta, 26, 71-138. 
Fauvel, P. (1896). Homologie des segments antérieurs des Ampharétiens (Annélides polychètes sédentaires). Compte Rendu Hebdomadaire des Séances de l'Académie des Sciences, Paris 123, 708-711.

Fauvel, P. (1897). Recherches sur les Ampharétiens, annélides polychètes sédentaires. Morphologie, anatomie, histologie, physiologie. Bulletin Scientifique de la France et de la Belgique, 30, 277-489.

Fauvel, P. (1927). Polychètes sédentaires. Faune de France, 16, 1-494.

Féral, J. P., Philippe, H., Desbruyères, D., Laubier, L., Derelle, E. \& Chenuil, A. (1994). Molecular phylogeny of the active Pacific Ocean hydrothermal vents alvinellid Polychaetes. Comptes Rendu de l'Academie des Sciences, 317, 771-779.

Gardiner, S. L. (1978). Fine structure of the ciliated epidermis on the tentacles of Owenia fusiformis (Polychaeta, Oweniidae). Zoomorphologie, 91, 37-48.

Hartmann-Schröder, G. (1996). Annelida, Borstenwürmer, Polychaeta. 2., neubearbeitete Auflage. Die Tierwelt Deutschlands, 58, 1-648.

Heimler, W. (1983). Untersuchungen zur Larvalentwicklung von Lanice conchilega (Pallas) 1766 (Polychaeta/Terebellomorpha). Part III: Bau und Struktur der Aulophora-Larve). Zoologische Jahrbücher (Anatomie und Ontogenie der Tiere), 110, 411-478.

Hessle, C. (1917). Zur Kenntnis der terebellomorphen Polychaeten. Zoologiska Bidrag från Uppsala, 5, 39-258.

Holthe, T. (1986a). Polychaeta Terebellomorpha. Marine Invertebrates of Scandinavia, 7, 1192.

Holthe, T. (1986b). Evolution, systematics, and distribution of the Polychaeta Terebellomorpha, with a catalogue of the taxa and a bibliography. Gunneria, 55, 1-236.

Hutchings, P. A. \& Peart, A. (2000). A revision of the Australian Trichobranchidae (Polychaeta). Invertebrate Taxonomy, 14, 225-272.

Jeener, R. (1928). Recherches sur le système neuro-musculaire latéral des Annélides. Recueil de l'Institut zoologique Torley-Rousseau, 1, 99-121.

Jouin-Toulmond, C., Augustin, D., Desbruyères, D. \& Toulmond, A. (1996). The gas transfer system in alvinellids (Annelida, Polychaeta, Terebellida). Anatomy and ultrastructure of the anterior circulatory system and characterization of a coelomic, intracellular, haemoglobin. Cahiers de Biologie Marine, 37, 135-151.

Maddison, D. R. \& Maddison, W. P. (2001). MacClade 4. Sunderland, Sinauer Associates. Malmgren, A. J. (1866). Nordiska Hafs-Annulater. Öfversigt af Kongl. VetenskapsAkademiens Förhandlingar, 22, 355-410.

McHugh, D. (1995). Phylogenetic analysis of the Amphitritinae (Polychaeta: Terebellidae). Zoological Journal of the Linnean Society, 114, 405-429. 
Meyer, E. (1887). Studien über Körperbau der Anneliden. Mitteilungen aus der Zoologischen Station zu Neapel, 7, 592-741.

Nilsson, D. (1912). Beiträge zur Kenntnis der Nervensystems der Polychaeten. Zoologiska bidrag från Uppsala, 1, 85-161.

Orrhage, L. (2001). On the anatomy of the central nervous system and the morphological value of the anterior end appendages of Ampharetidae, Pectinariidae and Terebellidae (Polychaeta). Acta Zoologica, 82, 57-71.

Picton, L. J. (1899). On the heartbody and coelomic fluid of certain Polychaeta. Quarterly Journal of Microscopical Science, 41, 263-302.

Pleijel, F. (1995). On character coding for phylogeny reconstruction. Cladistics, 11, 309-315. Rouse, G. W. (2001a). Chapter 59. Alvinellidae Desbruyères and Laubier, 1986. In G. W. Rouse \& F. Pleijel Polychaetes (pp. 235-237). Oxford: Oxford University Press.

Rouse, G. W. (2001b). Chapter 60. Ampharetidae Malmgren, 1866. In G. W. Rouse \& F. Pleijel Polychaetes (pp. 238-242). Oxford: Oxford University Press.

Rouse, G. W. (2001c). Chapter 62. Terebellidae Grube, 1850. In G. W. Rouse \& F. Pleijel Polychaetes (pp. 246-250). Oxford: Oxford University Press.

Rouse, G. W. (2001d). Chapter 61. Pectinariidae de Quatrefages, 1866. In G. W. Rouse \& F. Pleijel Polychaetes (pp. 243-245). Oxford: Oxford University Press.

Rouse, G. W. \& Fauchald, K. (1997). Cladistics and polychaetes. Zoologica Scripta, 26, 139204.

Rouse, G. W. \& Pleijel, F. (2001). Polychaetes. Oxford: Oxford University Press.

Sorensen, M. D. (1996). TreeRot. Computer program. Available via ftp://ftp.vims.edu/pub/hennig/TreeRot.sea.bin.

Swofford, D. L. (1998). PAUP*. Phylogenetic Analysis Using Parsimony (*and other methods). Version 4. Sunderland, Massachusetts: Sinauer Associates.

Thiébaut, E. \& Dauvin, J. C. (1992). Développement morphologique et croissance des juvéniles de l'Owenia fusiformis Delle Chiaje (Polychaeta, Oweniidae). Canadian Journal of Zoology, 70, 1701-1711.

Thorson, G. (1946). Reproduction and larval development of Danish marine bottom invertebrates, with special reference to the planktonic larvae in the Sound (Øresund). Meddelelser fra Kommissionen for Danmarks Fiskeri- og Havundersøgelser. Serie Plankton 4, 1-523.

Wheeler, W. \& Gladstein, D. (1994-2000). MALIGN. Software for multiple sequence alignment. ftp//ftp.amnh.org/pub/molecular/malign.

Winnepenninckx, B., Backeljau, T. \& De Watcher, R. (1993). Extraction of high molecular weight DNA from molluscs. Trends in Genetics, 9, 407. 
Zal, F., Desbruyères, D. \& Jouin-Toulmond, C. (1994). Sexual dimorphisms in Paralvinella grasslei, a polychaete annelid from deep-sea hydrothermal vents. Compte Rendu de l'Academie des sciences, Paris, Sciences de la vie, 317, 42-48.

Zal, F., Jollivet, D., Chevaldonné, P. \& Desbruyères, D. (1995). Reproductive biology and population structure of the deep-sea hydrothermal vent worm Paralvinella grasslei (Polychaeta: Alvinellidae) at $13^{\circ} \mathrm{N}$ on the East Pacific Rise. Marine Biology, 122, 637-648. 